\title{
IRYNEJ SKIRA (1950-2005): A SCIENTIFIC LIFE
}

\author{
by Lyndall Ryan
}

(with 15 plates)

Ryan, L. 2008 (31:x): Irynej Skira (1950-2005): A scientific life. Papers and Proceedings of the Royal Society of Jasmania 142(1): 9-20.

https://doi.org/10.26749/rstpp.142.1.9 ISSN 0080-4703. School of Humanities and Social Sciences, Faculty of Education \& Arts, Ourimbah Campus, University of Newcastle, PO Box 127, Ourimbah, NSW 2258, Australia. Email:

Lyndall.Ryan@newcastle.edu.au

The unexpected death of wildlife biologist, Dr Irynej Skira, at the age of 54 in February 2005, sent shockwaves through the scientific communiry. His longitudinal study of Short-tailed Shearwaters, Puffinus tenuirostris, also known as muttonbirds, was about to receive international recognition, while his recent second marriage appeared to open up a new chapter in his personal life. Who was this remarkable man, what was his contribution to science and what is his legacy? This article draws upon the funeral notes and memories of his family, friends and colleagues, to provide an overview of his personal and professional life. It shows how his two periods of fieldwork on Macquarie Island developed his interest in wildlife biology and how he extended it to assume responsibility for the longitudinal study of shearwaters. It explores his particular contribution to rhe study over nearly three decades and then discusses his wider contribution to conservation and preservation of wildlife in Tasmania. The article concludes with an assessment of his legacy.

Key Words: Irynej Skira, Short-tailed Shearwaters, Puffinus tenuirostris, muttonbirds, longitudinal studies, Tasmania, Macquarie Island, Fisher Island, The Snares, conservation.

\section{INTRODUCTION}

At the end of 2004, Irynej Skira had reached a turning point in his life. He had just married his second wife, Suzanne Frances Edwards, at a ceremony on his beloved Fisher Island. He had accepted an invitation to visit The Snares, the seabird sanctuary south of New Zealand and thus fulfill a long-held dream, and he had been invited to present a paper at the Second International Manx Shearwater conference in Belfast in Northern Ireland in August 2005. This was long-awaited international recognition that he was the world's foremost researcher on Short-tailed Shearwaters, Puffinus tenuirostris (Temminck, 1835) (called "muttonbirds" or "yollas" in Tasmania).

But he would not live to enjoy any of them. A month after his marriage to Suzanne, he set off for The Snares (pl. 1). An unsuspected heart infection erupted, leading to a stroke. He was airlifted to Dunedin by helicopter and flown back to Hobart a few days later. He died in the Royal Hobart Hospital on 18 February 2005 at the age of 54 .

Irynej's unexpected death sent shockwaves through the scientific community. At his funeral, in St Joseph's Catholic Church in Macquarie Street, Hobart, just up the street from his workplace, his long-time friend and colleague Nick Mooney told an overflowing congregation of grieving family, friends and workmates that Irynej had seemed indestructible. He had conducted his research into muttonbirds (pl. 2) for more than 25 years; he had weathered endless departmental restructures; he was a gentleman who valued politeness and scientific integrity; and his quiet professionalism gave him the aura of rock-like stability in "a sea of nonsense". His loss was irreparable (Mooney 2005).

Who was this remarkable man? What was his contribution to science? What legacy has he left us? This article attempts some answers to these questions.

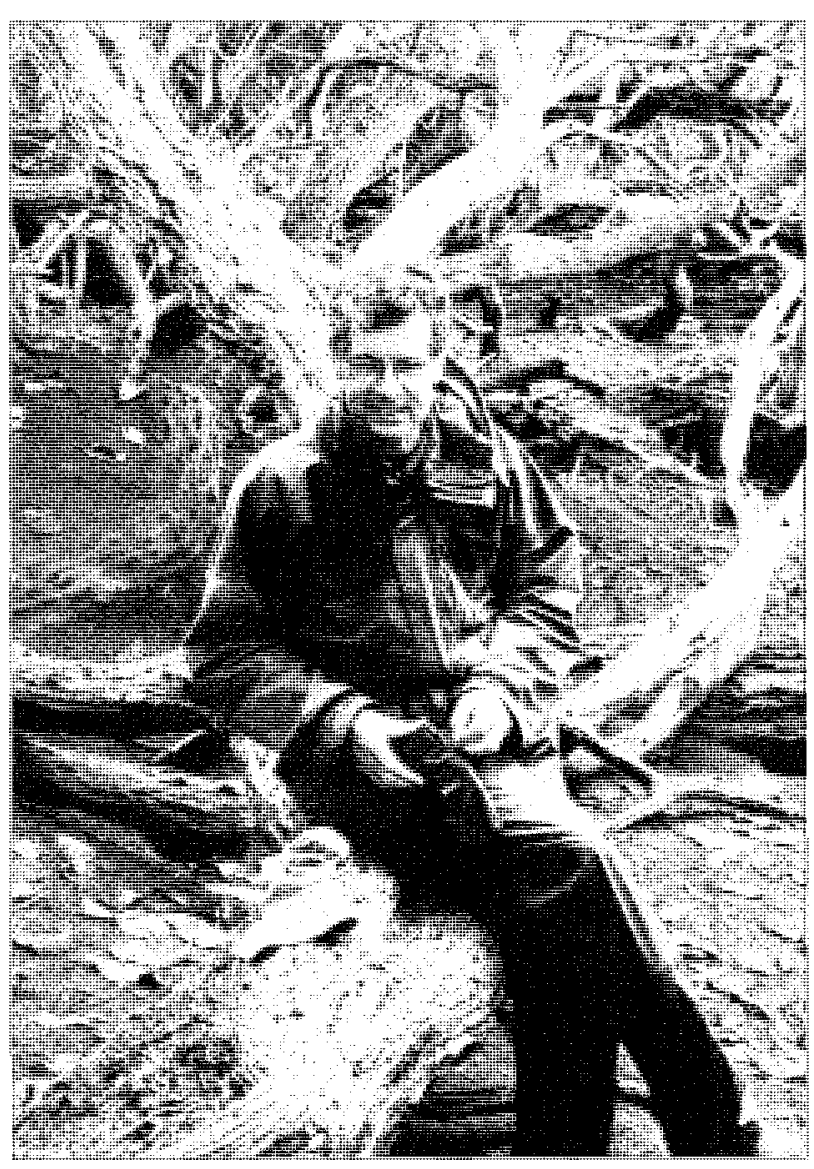

PLATE 1

Irynej Skira on The Snares, January 2005. (Photograph: Lisa Daglish) 


\section{CHILDHOOD 1950-71}

Irynej Osyp (Joseph) Skira was born at the Queen Victoria Hospital in Launceston, Tasmania, on 18 May 1950, the second son and middle child of Joseph and Irena Skira, who had arrived in Tasmania as refugees from Ukraine in late 1948. Born on the feastday of St Irene in the Ukrainian Catholic Church calendar, Irynej was named after St Irenaeus, a scholar and saint from the second century AD. According to his sister, Eva, his unusual first name (pronounced $i$-rin-ay) — which no one could say, spell or write in the then-conservative Anglo-Celtic culture - shaped his unique character from the outset (Skira, E. 2005).

Irynej told me that his father, Joseph, who had a background in engineering, and his mother, who had started a medical degree in Europe, had been given two choices of residence in Australia: Queensland or Tasmania. They chose the latter because of its cooler climate. In Irynej's view his family made the right choice. He was the first of their children to be born in Tasmania and from his early days had an empathy with his island home. He rarely felt the cold and appeared to be genetically attuned to the vagaries of the Tasmanian climate.

Joseph was employed as a foreman in a local saw-mill, initially out in the yard and maintaining the machinery, subsequently in an administrative position, while Irena took on part-time work as a nursing carer. They built a modest home at St Leonards, $12 \mathrm{~km}$ southeast of Launceston, in the shadow of Mount Barrow, and the family moved there in 1954. Both Joseph and Irena contributed widely to their community and became actively involved in school, church and Ukrainian associations, as well as the Launceston branch of the Good Neighbour Council.

Like so many postwar migrants with backgrounds in the professions, but unable to gain employment in their respective disciplines, Irynej's parents pinned their hopes on their children to achieve professional success by working very hard, valuing excellence in academic studies and expecting their children to have the same ethos; these values became a defining aspect of Irynej's character.

As a child, Irynej was shy and had a stammer that would remain with him all his life. In the 1980s Irynej had some speech therapy and his colleagues immediately bore the brunt of the new confidence through wit and cheek, at first putting it down to a new relationship (Nick Mooney pers. comm.). But he also had a bright, enquiring child's mind, and his mother remembers him as the most restless and exploring of her three children. Irynej later recalled finding native animals outside the back fence, building farm fences in the backyard, taking long bike rides into the mountains behind his home and joining the scouting movement, which fostered in him a love of bushwalking throughout Tasmania. At first he wanted to become a farmer, but after a while animal husbandry was replaced with a general love of nature and wildlife, in particular birds. His passionate relationship with the natural world was already well in train at this time.

He attended St Leonards Primary school and then St Patricks College in Launceston, from where he matriculated in 1967, excelling in Latin, mathematics and science. He also excelled at sport. He loved cricket and Australian Rules Football, although he did break his bones a couple of times, and he was a good runner and a good swimmer. He also learned the piano, but later said he was relieved when his music teacher suddenly died, and he no longer had to take lessons. His parents, however, had given him a deep love of classical music that would become an important source of enjoyment in adulthood.

Irynej also loved books. His sister Eva remembers that at home he would spend hours looking at reference books and encyclopedias that had both words and pictures. In his early adult years he began to collect some fine books, many cataloguing birds (Skira, E. 2005). This passion for collecting continued for the rest of his life. He also had an eye for black and white photography, drawing and sketching, later becoming interested in black and white prints.

In his later high school years, he worked in the long vacation in a saw-mill, where the incessant loud noise of the electric saws permanently deafened him in one ear - a not uncommon injury in an industry that, in those days, had no occupational health and safety regulations. Partial deafness became another factor in his defining status, together with partial colour blindness and short sight. None of these disabilities were of concern to Dr Bob Green, the curator of zoology at the Queen Victoria Museum, who took him on his first field trips and started him on the road to becoming a natural scientist.

In 1968, he went to the University of Tasmania to study for a Bachelor of Science degree, majoring in zoology, and moved to Hobart. At the end of his first year he gained a Commonwealth Scholarship to complete the rest of the degree. He excelled in fieldwork and bushwalked the southwest of Tasmania. By the time he had completed his undergraduate studies, there were few areas of his island home that he had not traversed on foot or by pushbike. He had already become a true Tasmanian.

\section{TASMANIAN PARKS AND WILDLIFE SERVICE AND MACQUARIE ISLAND 1972-77}

On Irynej's twenty-second birthday, as a "chirpy new science graduate" he began employment with the Tasmanian Parks and Wildlife Service (TASPAWS) as a park ranger at Cradle Mountain National Park (pl. 3). His colleague Trevor Weston, who started on the same day, later pointed out that science graduates were quite a novelty then and "Iry became the department's most highly qualified cleaner" (Mooney 2005).

"Iry" had other ideas. He wanted to join the scientific section of Wildlife. By the end of 1972, he was one of two biologists on Macquarie Island where TASPAWS had taken over rabbit eradication work from the Department of Agriculture. One of his duties was to record the number of cats and their colour. Many years later, it was found that Irynej's sample of cat colours did not match those of other researchers, ginger being under-represented. Everyone had forgotten his partial colour blindness (Mooney 2006).

According to Nick Mooney, Irynej came back from Macquarie Island inspired by curiosity-led research and, after a short stint at Lake St Clair National Park, returned to Macquarie Island for 16 months from November 1973 to March 1975 (pls 4, 5). He started studying the rabbit population with a view to impact assessment and control, setting up a monitoring program that is still in operation 35 years later. This led to his first scientific publications and became the basis of his MSc degree, which was awarded in 1980. Irynej demonstrated that as an active scientist he would make a contribution to scholarly research. 


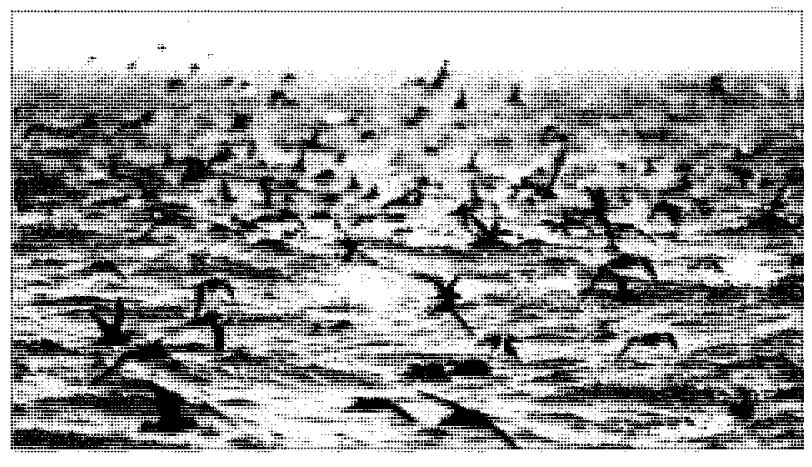

PLATE 2

Short-tailed Shearwaters, Puffinus tenuirostris, also known as "muttonbirds" or "yolla" in Tasmania.

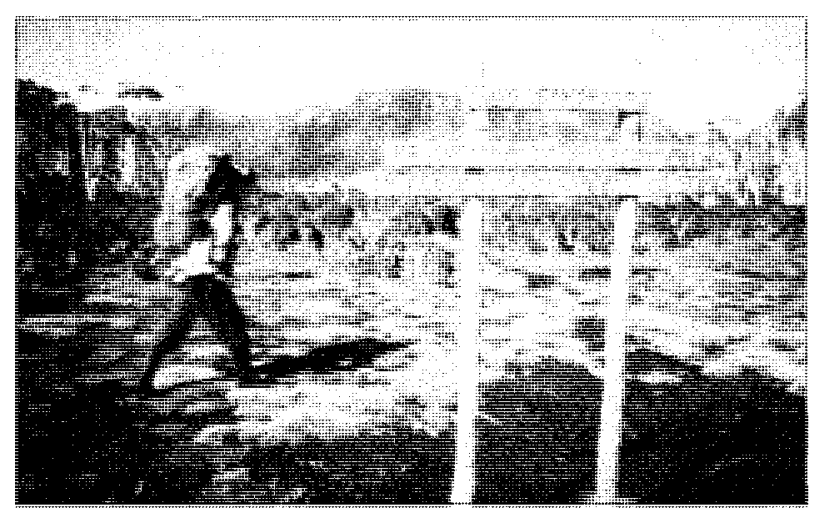

PLATE 3

Irynej Skira in Cradle Mountain National Park as a ranger.

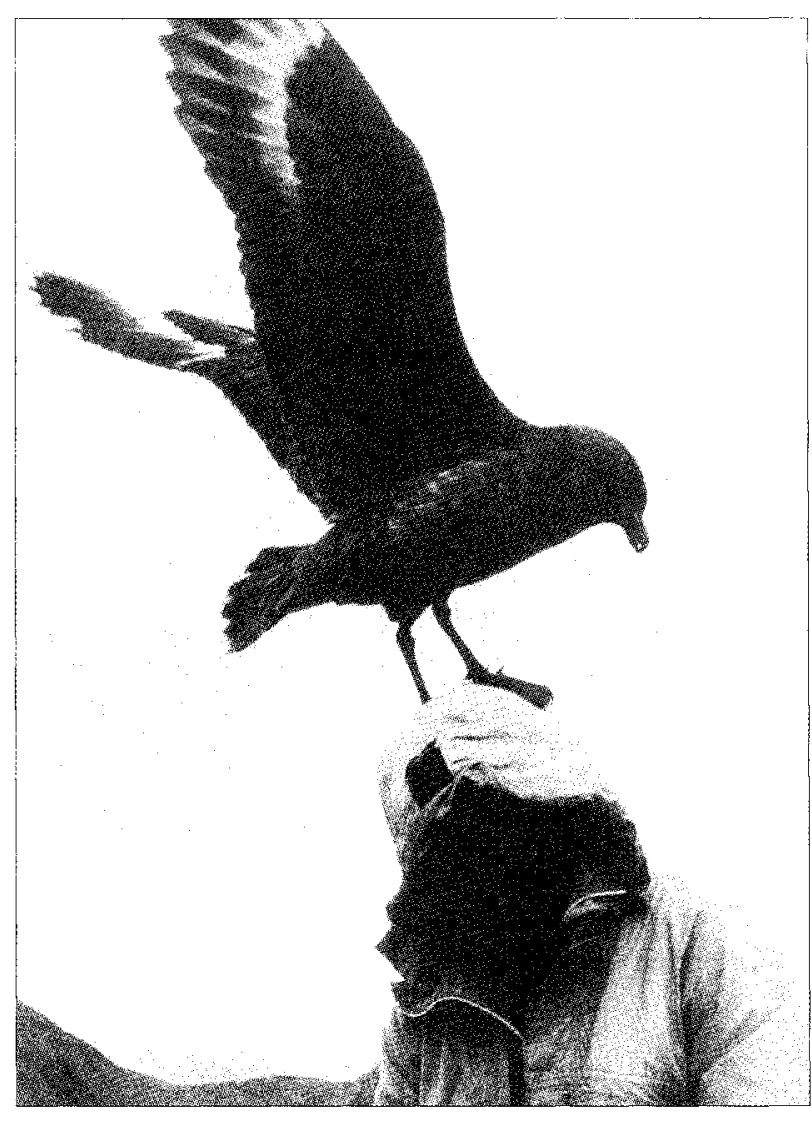

PLATE 4

Irynej Skira on Macquarie Island with a Brown Skua, Stercorarius antarcticus.

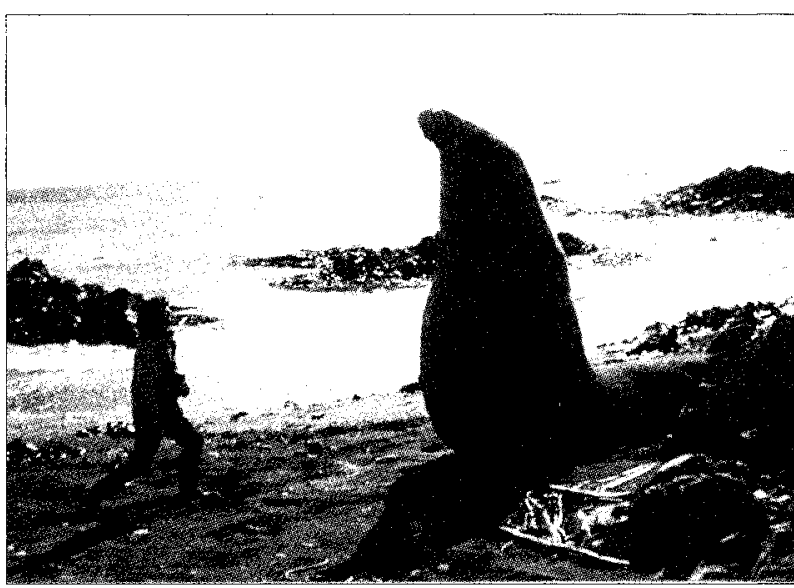

PLATE 5

Irynej Skira with a large male Elephant Seal, Mirounga leonina, on Macquarie Island.

On his second return from Macquarie Island, he lobbied hard for scientific input into wildlife management and eventually managed to transfer from the Parks to the Wildlife Section as one of its first scientific officers. According to Nick Mooney, "No doubt island life brought seabirds to Iry's attention and what better seabird to study on his return than the Short-tailed Shearwater" (Mooney 2006: 41). He was indeed well-suited to study this bird, because they are identified by the shape of their tails and wing spans, rather than by their colour. His short-sightedness enabled him to notice details of their eggs and burrows and his partial deafness attuned his senses to their smell and sounds. In studying the muttonbird, Irynej turned all his perceived physical disabilities into positive, even necessary, attributes.

\section{THE SHEARWATER/MUTTONBIRD PROJECT 1977-95}

In 1947, Dominic Serventy, one of the fathers of Australian ornithology, had started what would become 30 years' work on Short-tailed Shearwaters, a trans-migratory seabird that breeds only in southern Australia and migrates to the far northern hemisphere for the Austral winter. On their migration route the shearwater can fly over $16000 \mathrm{~km}$ each way, which is nearly the same distance as to the Moon and back.

The shearwaters return to Australian waters, largely to islands in Bass Strait, from September and their breeding timetable is strict. It was once thought that they all laid their eggs on the same day, which is close to the truth: $85 \%$ of all eggs are laid within three days either side of 24-25 November. The eggs are incubated for 54 days and chicks fledge about 100 days after hatching.

Dominic Serventy was determined to study the population dynamics and breeding habits of these birds, and to make them the subject of a long-term study. In 1948 he built a hut on Fisher Island in Franklin Sound, just off Lady Barron on the southern side of Flinders Island, and made it the centre of his research (pls 6,7). Much of this 0.8 hectare island is bare rock, with the rest covered with Poa tussock grass and friable soil.

By the mid-1970s, Serventy was ready to retire and persuaded TASPAWS to take over responsibility for research 


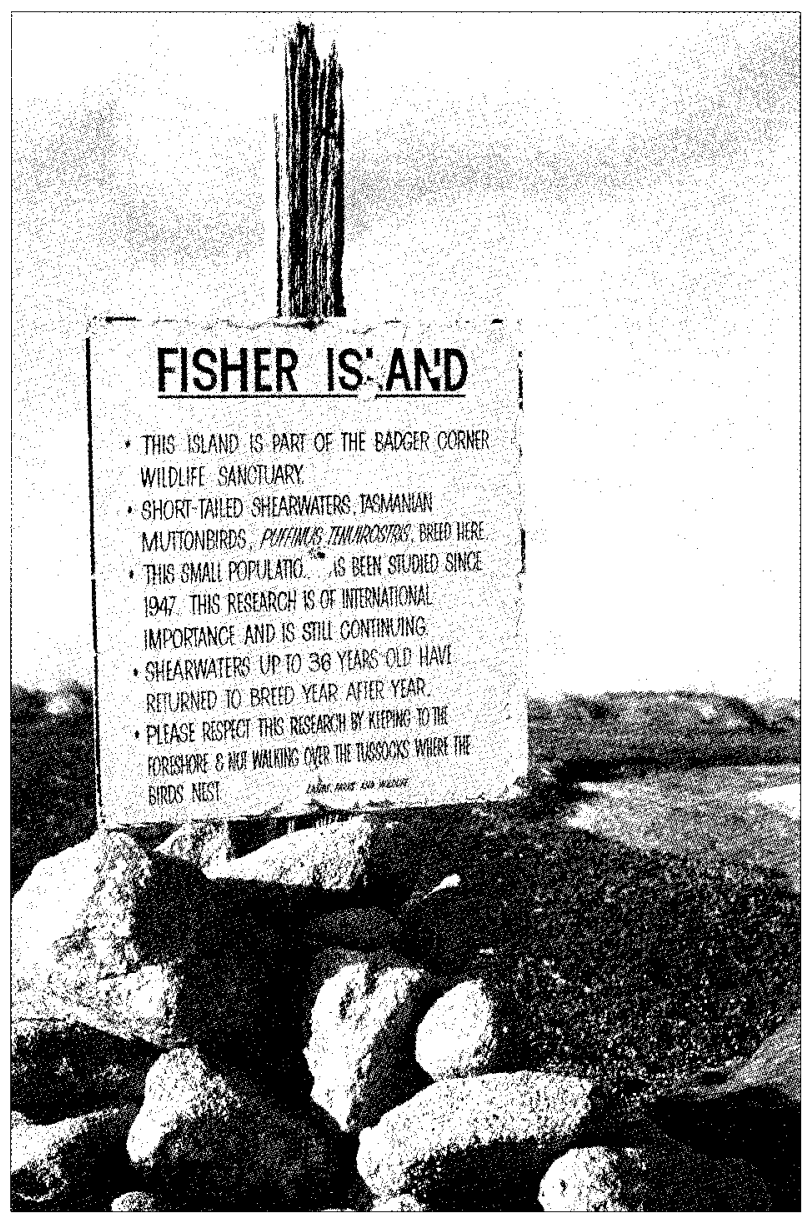

PLATE 6

Fisher Island off Lady Barron, Bass Strait home of the longitudinal study of Short-tailed Shearwaters.

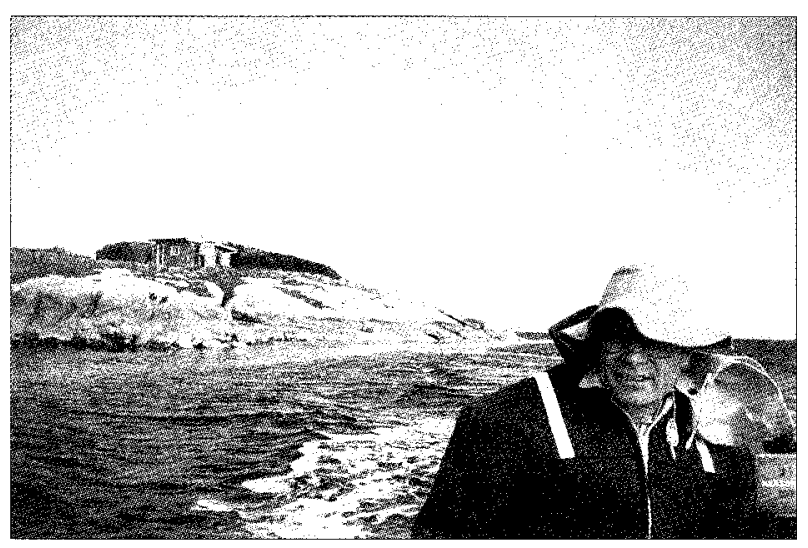

PLATE 7

Irynej Skira offshore from Fisher Island in December 1992. Clearly visible on the island is the hut from which the Short-tailed Shearwater study was, and is, conducted.

and management of the program. At first Nigel Brothers kept the study going, but Irynej, who had worked as Serventy's field assistant or "dinghy boy" in 1973, impressed the famous man and was anointed by him to continue his work (pl. 8). He could see that Irynej had an empathy with the muttonbirds, the tenacity for a long-term study

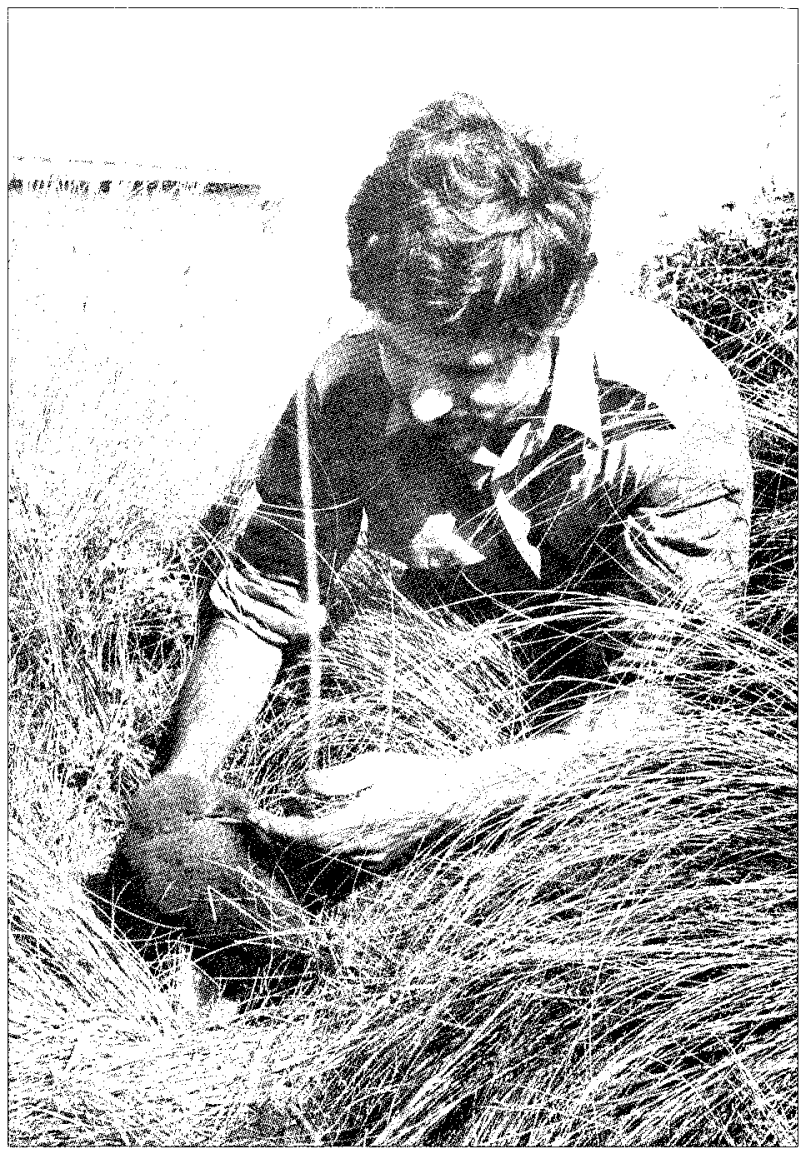

PLATE 8

Irynej Skira on Fisher Island in March 1976 when working as a field assistant for Domenic Serventy.

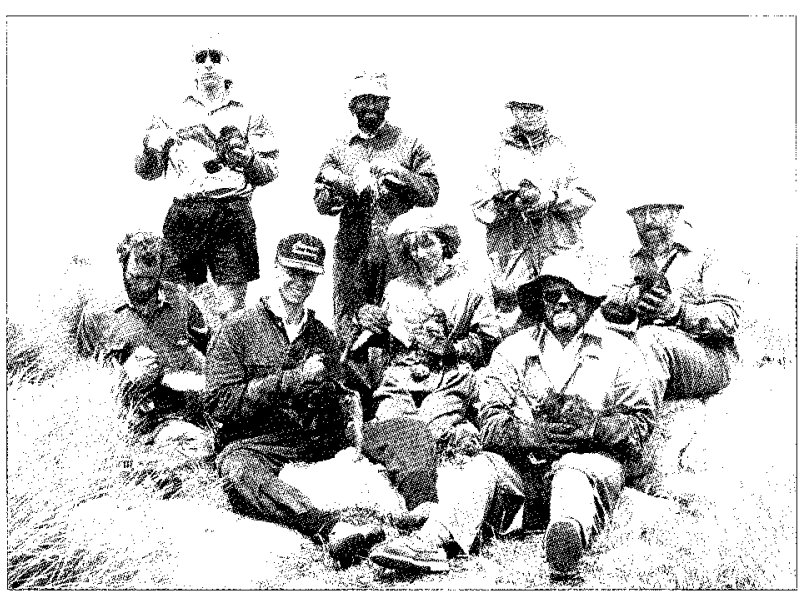

PLATE 9

Many who worked on the Short-tailed Shearwater project photographed on nearby Green Island in December 1988.

Back (standing) from left to right: Nick Parrott, Irynej

Skira, Anna Navin. Front (seated) from left to right: Rod Leaman, John Cassoti, Georgina Davis, Stuart Bradley and Ron Wooller.

and the scientific temperament to carry it out. I think, too, that he was impressed by Irynej's family background, for Serventy's parents were also migrants from Eastern Europe, who valued scientific study and had given him the work ethic of sticking with a long-term project. Irynej assumed 
formal responsibility for the program in December 1978 . Six months later Dom wrote to Irynej: "you are now thoroughly immersed in the Fisher Island work. When I come over in November it will have to be as your assistant" (Skira 2005b: 4).

Around this time two personal events occurred. First, his father Joseph passed away in July 1977, which had a significant saddening effect on the whole family, particularly Irynej and his mother. Second, in December 1978 he married Peggy Briggs, who was 17 years his senior and worked in the TASPAWS Office in Magnet Court at Sandy Bay. Earlier, before his first stint on Macquarie Island he had a relationship with a young woman, with whom he had a daughter Sarah, but it didn't work out. He later told me he was "a wild young man back then", with a penchant for motor bikes, which he rode at breakneck speed up the Midland Highway. Marriage to Peggy gave him confidence and maturity.

By then he looked like everyone's idea of a wildlife biologist. He had a lean frame and dark, good looks, with large brown eyes, longish, dark curly hair and a beard, and wore glasses. He was more at home in the TASPAWS field uniform of dark green trousers, shirt and jacket than an office suit, and clearly preferred the uncertainties of fieldwork to the more predictable life of the office. As a settled married man he was well-suited to continue what would become the world's longest longitudinal study of any seabird in the world.

Fisher Island would become the central focus of his professional life for the next 25 years and the jumping-off point for several important projects, scientific and nonscientific (pl. 9). It is extraordinary that this small island would be the centre of a rich scientific life that opened up new worlds for Irynej in so many different directions. As Suzanne Skira later wrote:

Research on Fisher Island forms the cornerstone of all management decisions on the species. Here Irynej observed many aspects of shearwater life, including population dynamics, survival, breeding and feeding. One of the strengths of the Fisher Island study is its simplicity of monitoring. Approximately 80 pairs breed on the island each year in three discreet colonies: Home Rookery, South Rookery and Potts Point. All the burrows are mapped and have their own pole with an identification number. Irynej determined burrow occupancy by using a stick $60 \mathrm{~cm}$ long to feel inside the burrow. If it was occupied he gently removed the bird, recorded the sex and band number and checked for an egg. New birds were banded and old bands replaced.

(Skira 2005b: 4-5)

Irynej led fieldtrips to Fisher Island three times a year: in December to count the eggs, in March to count and band the chicks and in April to monitor the muttonbird "harvest" on other islands in Bass Strait. It was arduous work, but Irynej, undaunted, extended Dom Serventy's work of banding the birds by monitoring them in their burrows with transects (pl. 10), and with blood and feather sampling as well as weighing and measuring. According to Nick Mooney, Fisher Island also provided first-class field experience for new employees in TASPAWS over the next 28 years.

The benefit of the shearwater experience and a stint on Fisher Island became a rite of passage for several generations of local scientists, rangers, students and naturalists. He introduced TASPAWS rangers to the

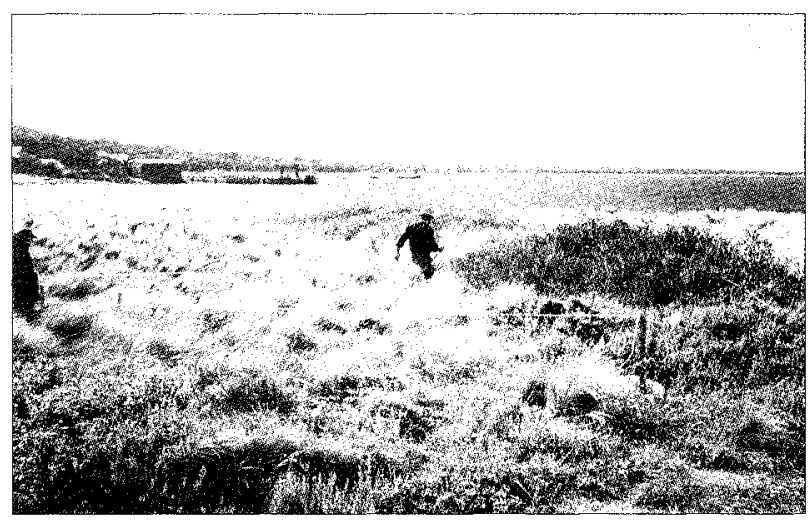

PLATE 10

Original transects on Fisher Island were laid down by Dominic Serventy with these same poles. Here they are monitored by Irynej Skira (centre) in 1995.

eccentricities of scientists and the cooperation and discipline needed for long-term scientific research."

(Mooney 2006: 41)

In those days, Occupational Health and Safety guidelines were "a matter of self reliance and common sense" and mobile phones had not yet been invented. When contact was necessary, the ranger on Flinders Island would sometimes fire a gun from the shore to try to get Irynej's attention. It was only when Irynej got an outboard motor in the mid1980 s that there was an accident. A senior ranger (no less than Peter Mooney, brother of Nick Mooney) fell out of the dinghy and had to tread water for over an hour until the circling dinghy ran out of petrol, before he could rescue himself. It is testimony to Irynej's great care and preparation that more serious accidents did not occur.

Nick Mooney later pointed out:

Many of us met our first muttonbirds on Fisher Island.

The early morning and late evening stints, arms buried in shearwater burrows, the battle of wits with the local rats, Iry's bashing of abalone, and the endless rowing of a battered dinghy are all etched in our minds."

(Mooney 2006: 41)

In this way he trained many generations of young and not so young scientists in the art of recording and banding the birds. He also trained them in thorough preparation for fieldwork, an essential aspect of the life of a field biologist. This included the ordering of food supplies and scientific equipment and how to account for everything on the tightest possible budget. His field notebooks, which contain his distinctive "scientific" style of handwriting and recording observations, stand as a model of scientific note-taking, while his black and white photographs are testament to his keen eye for detail.

Over the next two decades, Irynej published more than 40 scientific papers on the population dynamics of the shearwaters and other seabirds. He found that their population is about 23 million adults and that they first breed between four and five years of age and can live up to 38 years. He also found that there are 250 muttonbird colonies in Australia, of which over 200 are in Tasmania, comprising $80 \%$ of the total population. The colonies are distributed around the coast of Tasmania and its offshore islands. The largest colony is on Babel Island, with over two million burrows. By the time of his death in 2005, more than $70 \%$ of the breeding colonies were protected 
on reserves.

In 1981 he gained a grant from the Australia-Japan Foundation to study seabirds and Japanese Snipe, Gallinago hardwickii (J.E. Gray, 1831), in Japan, and in 1985 gained a further grant from the Yamashina Institute of Ornithology in Japan to follow the seasonal patterns of migration of the muttonbird, from Bass Strait to the Bering Strait, the west coast of Canada and across the Pacific Ocean back to Bass Strait. To this end he made a six-week return voyage on a cargo ship from Japan to the west coast of the United States via Hawaii.

This extraordinary journey brought home to him the international and regional significance of the shearwaters and how they were an important marker of climate change. He published several papers that noted increases in ocean temperatures in various parts of the Pacific Ocean in different seasons and the effects on the muttonbird's migratory habits. A paper he published in 2003, for example, indicated that the increase in winter ocean temperatures off the east coast of New South Wales in 1999 had resulted in there being insufficient food for the muttonbirds, which had led to a significant increase in the death rate, far beyond the norm, and that a further increase in ocean temperatures in the following years had led to another increase in muttonbird deaths (Skira 2003b). By then scientists had identified El Nino and its effect on drought in Australia. Irynej's interest, however, was the impact on muttonbirds. Put together with Dom Serventy's work, the longitudinal study provided important information about the fluctuations in bird populations and in ocean temperatures over nearly 60 years.

As Nick Mooney pointed out:

These long-term studies are both rare and valuable: rare

because they require dogged persistence and valuable

because they show natural fuctuations in populations over meaningful periods of time and, thus, can also reveal abnormal change. Some of Iry's study birds were actually older than him - at one stage, one was at least 46 years old" (Mooney 2006: 41).

Suzanne Skira noted that when she worked with Irynej on the island in 2003 that "the older pre-banded birds seemed to anticipate Irynej's handling and remained calm." (Skira 2005b: 5)

The legacy of this work is that Irynej produced the best knowledge in the world on the ecology of shearwaters, which has led to better protection and conservation of species. Above all he demonstrated the value of long-term monitoring programs.

\section{THE SHEARWATER PROJECT AND THE TASMANIAN ABORIGINAL COMMUNITY}

One of the first groups of people Irynej met when he became responsible for the shearwater management program was the Aboriginal community, which had been engaged in seasonal muttonbirding since time immemorial and on a commercial basis since the early nineteenth century (pl. 11).

Two Aboriginal women, Marge Mansell and Phyllis Pitchford, showed him how to pluck muttonbirds and how to locate the best burrows. After Irynej had finished his Master's degree, he began to realise that the history of muttonbirding in relation to the Tasmanian Aborigines and other human groups needed serious study, so he enrolled as a doctoral candidate at the University of Tasmania. At his

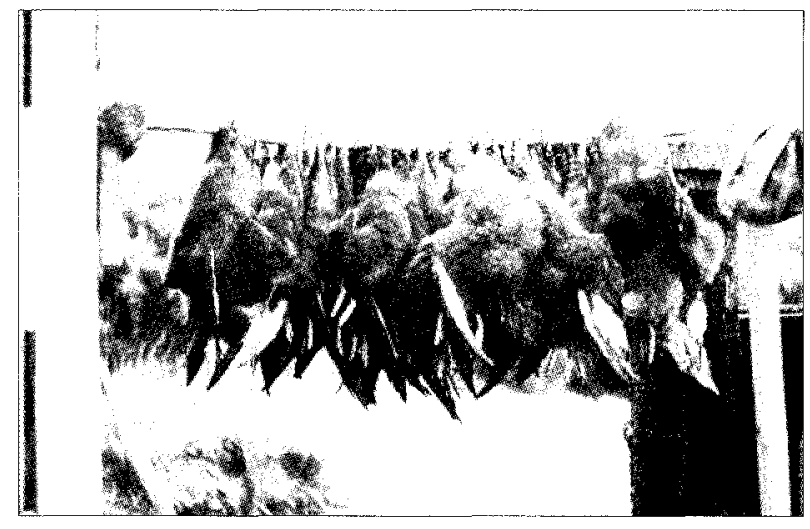

PLATE 11

Harvested muttonbirds in the Bass Strait islands.

PhD ceremony dinner some years later, Irynej told me that he had great difficulty in finding a university department and a supervisor for the project. Eventually he was accepted by the Environmental Studies program in the Geography Department, where he was supervised by Peter Hay, who had enormous faith in Irynej and the project. He rapidly mastered the disciplinary demands of historical research, and set about the task with flair and confidence.

In the first section of the thesis, Irynej set out the ecology of the muttonbird, from its evolution, distribution and abundance, migration, feeding, breeding biology and mortality rates. This was based on his own scientific research over the previous decade. In the next section he outlined the exploitation of muttonbirds in the past by the Indigenous peoples in Tasmania and on the east coast of Australia, as well as in New Zealand and the northern hemisphere. For this information he drew on archaeological papers, reports and theses and revealed for the first time the importance of muttonbirds as a major source of food and ritual in these societies.

In the third section, he outlined the arrival of European explorers and sealers to Tasmania in the early nineteenth century and their interaction with Aboriginal people in northern Tasmania, which led to the development of the Islander community in Bass Strait in the later nineteenth century and their conflict with European farmers and settlers who took out leaseholds on the islands to graze sheep and cattle. He then explored social change in the Islander community in the first half of the twentieth century, in relation to the Cape Barren Island Reserve Acts of 1912 and 1951 and their impact on the muttonbird industry. The final section of the thesis explored the commercial aspects of the industry to the present (Skira 1993).

Irynej produced a bold and innovative thesis, one of the first in Australia to explore the relationship between food resources and human groups in the past and the present. The examiners were historians, a prominent environmental historian in one instance, and a historian of Aboriginal-European interactions on the other. The doctorate awarded in 1995 was the pinnacle of his career to that point. In Hay's opinion, its disciplinary sweep makes it an extraordinary study. It is a great tragedy that it has never been published. 


\section{EXTENDING HORIZONS 1995-2005}

By then Irynej's marriage to Peggy had ended and his older brother, Peter, had died, leaving a deep emotional scar. He moved to a cottage at Kingston Beach and was often seen in Hobart scouring bookshops for rare titles and taking coffee with friends at Fullers Bookshop. He shared an interest in antique colonial furniture with Ray Prince and in painting with George and Mary Davis. Over the next five years, he met a number of women with whom he developed very close relationships, but none could match his emotional depth and intensity. He would have to wait a few more years before he found the woman who did. In the meantime his close friends could see that he was unsettled and unfulfilled. He was sustained by exciting new developments in the study and management of muttonbirds.

In the late 1990s, he made contact with the Màori community in New Zealand to learn the ways they engaged with muttonbirding. In 1999 he hosted four New Zealand scientists on Fisher Island to "... look at the Tasmanian muttonbird harvest and ecological research" (Moller 2000: 4). Henrik Moller was

"... amazed (and envious) of the detailed scientific
knowledge of the Short-tailed Shearwater. They have
measurements of the size of pretty well every colony in
all of Australia and one very long study of the birds on
Fisher Island. It shows the value of long term research
- those scientists over there have been banding and
surveying their muttonbirds for 50 years!" (Moller
2000: 4)

He also noted that Irynej had recorded their lives in ways that more than matched records of human activity. "One bird had outlived two lots of metal bands, and was last seen in 1994 at the age of 38 years" (Moller 2000: 6).

Irynej used their visit to initiate contact between the Maori community in New Zealand and the Aboriginal community in Tasmania so that they could visit each other during the muttonbird season and explore and understand the different ways they conducted the ind ustry. He also obtained funding from the Contract Employment Programs for Aborigines in Nature and Cultural Resources Management to employ up to ten Tasmanian Aboriginal people to undertake research into muttonbirds from an Aboriginal perspective.

His enthusiasm for collaboration with scientific colleagues was a marked feature of his career. According to Nick Mooney, "his many co-authorships are testament to his extensive collaborations" (Mooney 2006: 41). He never worried overly about his ownership of data and always welcomed people to the field. For example, when I arrived in Tasmania in February 1995 to collect new material for the second edition of my book, The Aboriginal Tasmanians, he gave me access to his own unpublished doctoral thesis and read many drafts of my manuscript. I admired his ability to deal with pressure, manage ambiguity and change in dealing with the Aboriginal community over "cultural muttonbirding" and the way he balanced their claims against environmental, social and regulatory concerns, and Government policy. Here was a scientist who really cared about Aboriginal people and the muttonbirds and the place of both in a complex environment. He also helped students from mainland Australia and overseas universities with shearwater and gull studies, some on his beloved Fisher Island. He also shared his wealth of knowledge with local students, wildlife care groups and any interested volunteers.
This is the sign of a true scholar.

Irynej also encouraged artists and writers to visit Fisher Island and they often gave him some of the products of their creative endeavours. When I first met Irynej in 1995, he had a significant collection of drawings of plants and birds as well as paintings of Fisher Island and the surrounding islands in Bass Strait. He encouraged many friends to join him for a week or so at a time, to give them a break from their own busy lives, but in reality to assist him in recording and banding the birds. In 1997, he hosted a Fisher Island fiftieth birthday party in Hobart, inviting all those who had been there, ro join him in the celebrations. The large turnout of people from a wide variety of backgrounds, including medicos, academics, artists and writers as well as his scientific colleagues, is testament to his wide circle of friends who were proud of their association with him, with Fisher Island and with the project.

Irynej's professional life as a wildlife biologist also continued to vary. For example, he helped with the small mammal surveys on Hunter Island and even joined Nick Mooney in search of thylacines after the famous 1982 report by Hans Naarding. Nick always found him good company, "suitably eccentric and quick to laugh, with a dry, incisive wit. We didn't always agree, but why would we want to?" (Mooney 2006: 41)

In 1993, he gained a significant grant from the Australian Nature Conservation Agency and National Estate to investigate the threat from the North Pacific seastar on native marine invertebrates and became a founding member of the Seastar National Taskforce.

After the Iron Baron oil spill in Bass Strait in 1996, Irynej took responsibility for organising the response equipment, and helped with seal surveys in Bass Strait. At other times he moved, to Bass Strait, errant seals which had attacked salmon farms in southern Tasmania. This involved capturing the seal and putting it in a saltwater tank in a cage on a trailer and then towing it up the Midland Highway for release at a beach at the mouth of the Tamar River. At one stage in 1996 and 1997, he was making four or five trips a week, a terrible waste of his scientific skills and abilities. Then he became part of a seal tagging program and assisted in tracking the remarkable behaviour of "Radar", an adolescent male seal which he captured several times at salmon farms and then released into the Tamar before it finally disappeared into the South Pacific Ocean. "Radar" aroused considerable media interest and Irynej was photographed at least once in the Hobart Mercury, with his boisterous charge in tow.

But Irynej was equally famous for not doing things that he thought were a waste of time or just plain silly. Every now and then he would apply for promotion to a senior position, only to be told that he should wear a suit and attend more meetings. As his colleague Nick Mooney recalls: "few of us escaped the odd sharp rebuff in this regard" (Mooney 2005: 3).

Among Irynej's more thankless tasks, was as secretary to the Department's Animal Ethics Committee, where he had to endure some aggressive lobbying and, at times, rather nasty criticism, which he weathered with complete professionalism. Other tasks included responsibility for government management of zoos and wildlife parks in Tasmania — a frustrating and difficult task for a wildlife biologist. However, he dealt with the managers of these outfits more successfully than his predecessors by adopting a firm but civilised approach and by refusing to be drawn into slanging matches. His exemplary professional behaviour as 
government representative on the Antarctic Animal Ethics Committee also stood him in good stead.

Another aspect of his professional life was his membership of the Australian Bird Study Association. He contributed to the Seabird Island Series and was the driving force in the preparation of 15 of the subsequent 25 descriptions of Tasmanian Islands.

In the twenty-first century, recognising the value in understanding common species - perhaps those most important to ecosystems - Irynej became increasingly frustrated with the trend towards studying or conserving only things that were on the Endangered Species List. He also despaired of the destruction of Tasmania's old-growth forests, lamenting that protective protocols applied only to endangered species, guaranteeing the endless logging of timber.

In 2003, he disputed the demand by the Mayor of the West Coast that bag limits for commercial muttonbirding should be increased. He was alwavs concerned about overharvesting:

The limits are there for a reason. Only one third of chicks return to breed, laying just one egg per season after they reach the minimum of five years of age. Mortality rates are high with 10\% of adults dying each year. Every muttonbird season more than a quarter of all burrows are badly damaged and vegetation destroyed. all to reach one bird. I've seen evidence of not only a spade being used to get to a bird, but where people have punched through the earth because they can't reach the end of the burrow. There are places where vegetation has been taken to with a chainsaw to obtain easier access. (Skira 2003a)

He gained some of the first National Heritage Trust grants for feral species management and organised cat control on seabird islands in the Furneaux Group, and pig control on Flinders Island. He then helped with a biodiversity survey on a large midlands property and began to realise that it could be the centre of another long-term study. This determination to do practical things was typical of his nature.

It is fitting that Irynej would meet his soul-mate at a muttonbird colony. He always believed that he should educate the public about shearwaters and every summer he led public field tours at Clifton Bluff muttonbird colony near Hobart. There in 2000, he met Suzanne Edwards, who was a nurse. They had an instant rapport, and it was not long before they began to plan their future together. When they were married on Fisher Island in December 2004 (pl. 12), they both believed that their best years lay ahead. His friends were delighted that he had at last found personal happiness and fulfillment. One of them built a new house to the couple's specifications at Kingston Beach, which included a specially designed library for Irynej's collection of rare books, prints, stamp collections and antique colonial furniture. They expected to move in when Irynej returned from The Snares in February 2005.

\section{THE SNARES}

Irynej always had an irresistible sense of mission to go to The Snares. Its extraordinary diversity of seabirds as well as its remoteness held an attraction that matched his passion for Macquarie Island. However, the opportunities to go there were few and far between. When Henrik Moller invited him to join an expedition with Chris Powell and Corey Bragg

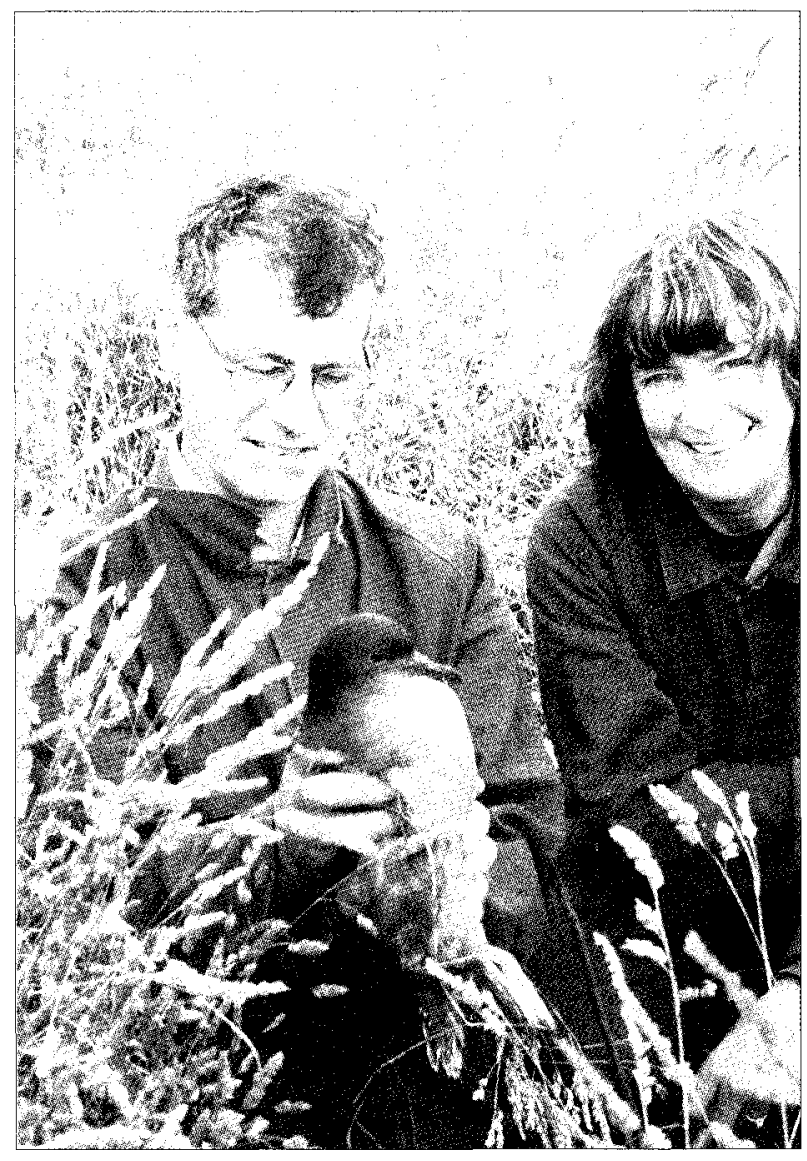

PLATE 12

Irynej and Suzanne Skira on East Kangaroo Island on 13 December 2004, prior to their wedding on Fisher Island. (Photograph: Dawn Zelman).

from the University of Otago at Dunedin, he believed it was an impottant moment in his scientific career.

According to his wife, Suzanne, Irynej was feeling tired the day he left for Dunedin. But they put it down to the strain of preparation for this long-awaited trip and believed that once he got under way, he would return to "normal", a word he often used to describe the ordinary. Besides, he had always enjoyed extraordinarily good health and could barely recall a day's illness. When he arrived in Dunedin he told Suzanne in an email that he still felt tired, but that the excitement of almost being at The Snates had taken ovet.

He arrived on Friday, 21 January 2005 and had time to record in his diary every animal and bird he came across before his last entry three days later: "Nice calm morning. Blue skies. Got up approx 6 am - noisy shearwaters everywhere". By the end of the following day, he was fighting for his life and awaiting transport by emergency helicopter to Dunedin Hospital. He died in Hobart 25 days later.

The last diary entries struck a chord with his colleagues. According to Nick Mooney, they were:
.. 100\% Irynej - thorough and dry. He was obviously
pleased to be there, in the best of company, both people and wildlife - sea lions, shearwaters and a black tom tit. I'm sure he wouldn't mind me saying he more or less died with his boots on." (Mooney 2006: 41) 


\section{INTERNATIONAL RECOGNITION}

When news of Irynej's death reached the international scientific community, the Second International Manx Shearwater Workshop in Belfast was dedicated to his memory. There his wife Suzanne presented a paper to a hushed audience that understood, perhaps for the first time, his immense contribution to the field (Skira 2005b). Obituaries followed in several scientific publications and journals devoted to the study of birds (Moller 2005, Murray 2005, Sharpe 2005 , Skira 2005c, Mooney 2006).

\section{LEGACY}

Irynej Skira was a professional wildlife biologist with the Tasmanian government for almost 33 years. Originally TASPAWS, by the time he died, it had transmogrified into the Nature Conservation Branch of the Tasmanian Department of Primary Industries, Water and Environment. He used his position genuinely and tenaciously to strive to work towards the conservation of the species ( $\mathrm{pl} .13$ ), in fact it was his life's work. How many of us can say that we have given our lives for a cause?

As his sister, Eva, noted in her eulogy at his funeral, it could be argued that Irynej's professional interest in seabirds in general and muttonbirds in particular was shaped by four islands. The first is the island of Tasmania, where he was born and grew up and which ignited his love of the natural environment. The second is Macquarie Island, where he conducted his first scientific fieldwork and began his professional career as a scientist. The third is Fisher Island, where his long-term study of the population dynamics of muttonbirds, established him as a scholar of international repute. And the fourth is The Snares, which he believed contained the secrets of the habits of several seabirds (Skira, E. 2005). It is a tragic irony that he was struck down on the island that he had longed to visit.

A quiet, gentle, softly spoken, unassuming and unique man, with a dry, ironic sense of humour, Irynej's devotion to environmental science was greatly admired and respected by his peers. Henrik Moller noted his "gentle, tolerant, generous nature - a real gem of a man as well as a fine scholar" (Moller 2005: 4). Nick Mooney believed that his "extra effort born of enthusiasm, curiosity, discipline and a positive attitude", "those extra yards and minutes", got Irynej his achievements (Mooney 2005: 5). His PhD supervisor, Peter Hay, told me he had the attributes of a Renaissance scholar. He was a first-class scientist, widely read across a huge range of disciplines, with a deep love of music, painting and photography and open to new ways of studying the world. His wife Suzanne noted that "he moved gently on the earth but left behind a huge legacy". He showed how one person's commitment and personal endeavour can make a difference. It is a tragedy that at the moment when he found personal happiness and achieved international recognition, his life was cut short. His premature death brought to an end a remarkable and passionate relationship with nature.

The chief legacy of Irynej's work was to demonstrate the immense importance of long-term monitoring of seabird populations (pl. 14). A quote from the paper Suzanne presented to the conference in Belfast in August 2005 forcefully shows this:

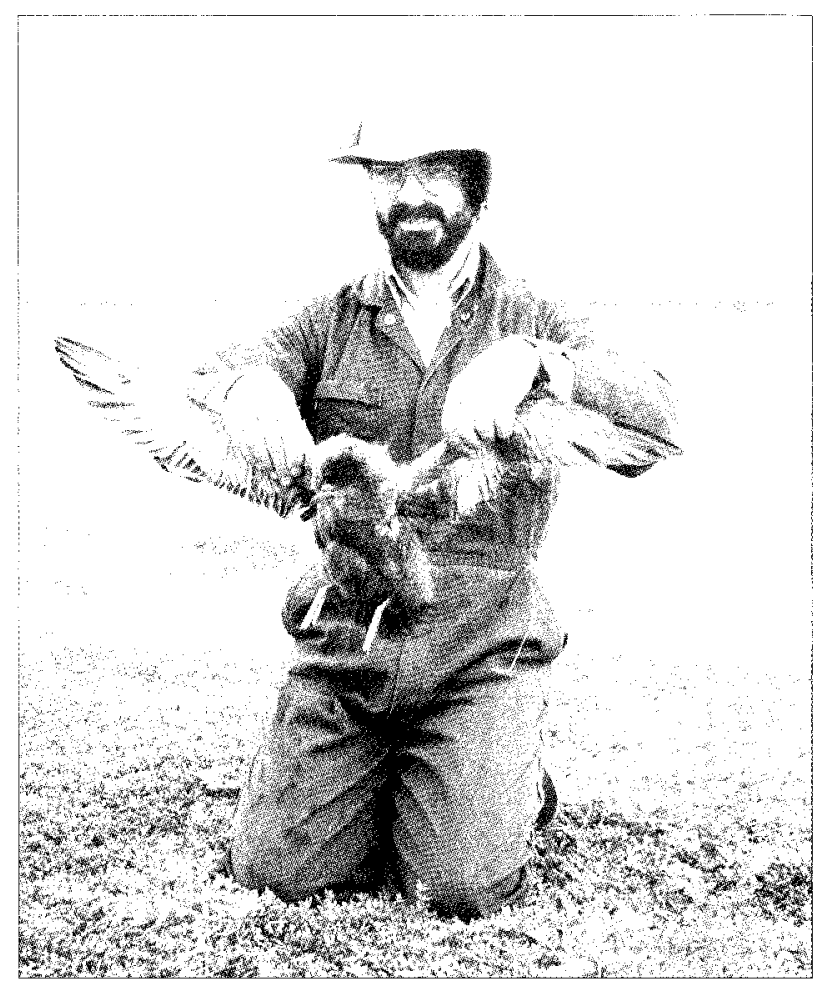

PLATE 13

Irynej Skird with a young Short-tailed Shearwater, the species whose conservation formed a large part of his scientific life.

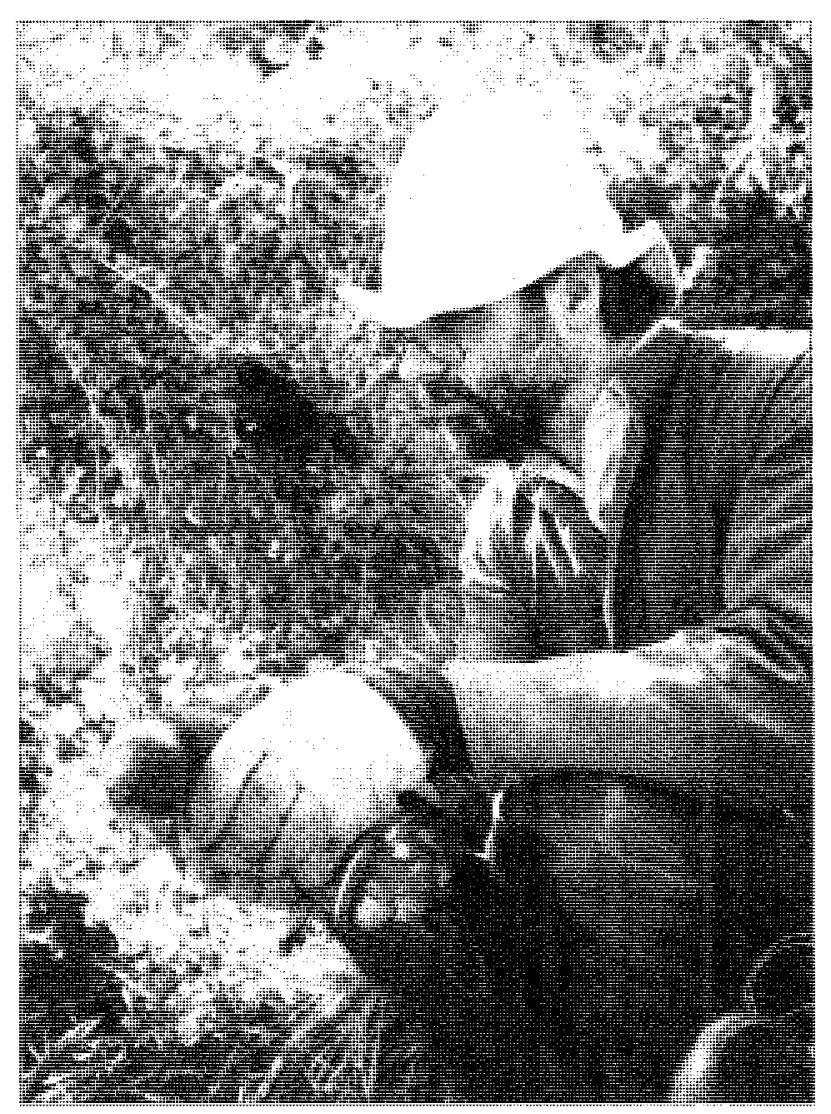

PLATE 14

Irynej Skira with a Short-tailed Shearwater removed from its burrow as a part of the long-term monitoring programme. 
Short-tailed Shearwater populations are difficult to gauge without having access to long-term data sets. More than 50 years of data are available on Short-tailed Shearwaters on Fisher Island, but the small breeding population makes it difficult to determine whether large-scale climate. influences or others factors are influencing the population. Nevertheless, such data serve as a starting point. Seabirds are an important indicator of changes in global climate. Long-term data sets are the crucial answer to the problems of seabird population fluctuations.

But, long-term monitoring needs long-term support and this can probably only come from government. But in Irynej's view anyone contemplating long-term study should also actively seek publicity in order to anchor their research in the public mind. It then makes it harder to terminate. The publicity generated by shearwaters, largely through their own amazing lifestyle (pl. 15), has always been of great media interest and has helped keep the work alive (Skira 2005b: 6).

This issue is homage to this remarkable man and to his extraordinary work.

\section{ACKNOWLEDGEMENTS}

I would like to thank Peter Hay and Clive Tilsely for sharing their memories of Irynej and commenting on earlier drafts. I would particularly like to thank Eva Skira for sharing her memories of Irynej's childhood, providing a copy of her funeral oration on Irynej and for her sound editorial skills. I would also like to thank Nick Mooney for allowing me to use his eulogy and obituary of Irynej, to flesh out his scientific career. Above all I would like to thank Suzanne Skira for sharing her memories of Irynej's later life and sending me copies of his publications as well as her own and others, to understand his scientific legacy. Any mistakes or oversights are my own.

\section{REFERENCES}

Moller, H. 2000: Taking a look at the Tasmanian Titi Harvest. Titi Times 7, February: 4-7.

Moller, H. 2005: Farewell and thanks to Irynej, Titi Times 15, July: 4.

Mooney, N. 2005: Eulogy for Irynej Skira. Unpublished (copy in possession of the author).

Mooney, N. 2006: Dr Irynej Skira: 18 May 1950-18 February 2005. Wingspan 16(1): 41.

Murray, D. 2005: Irynej Skira (18 May 1950-18 February 2005). Australian Bird Study Association Newsletter 78: 6.

Sharpe, D. 2005: Dr Irynej Skira: scientist and naturalist. Aurora ANARE Club Journal 24(4): 21

Skira, E. 2005: Irynej Joseph Skira 18-5-1950-18-2-2005. Funeral Address: 24 February 2005. Unpublished (copy in possession of the author).

Skira, I. 1993: Tasmanian Aborigines and Muttonbirding: a Historical Examination. Unpublished PhD thesis, University of Tasmania, Hobart.

Skira, I. 2003a: Biologist disputes bird claim. Advocate 13 May.

Skira, I. 2003b: Large mortality of short-tailed shearwaters Puffinus tenuirostris in Australian and New Zealand seas in October 2000. Corella 27(3): 81-84.

Skira, S. 2005a: Soaring legacy of a gifted scientist. The Mercury, 25 April.

Skira, S. 2005b: Maintaining the Passion: Reflections on the life

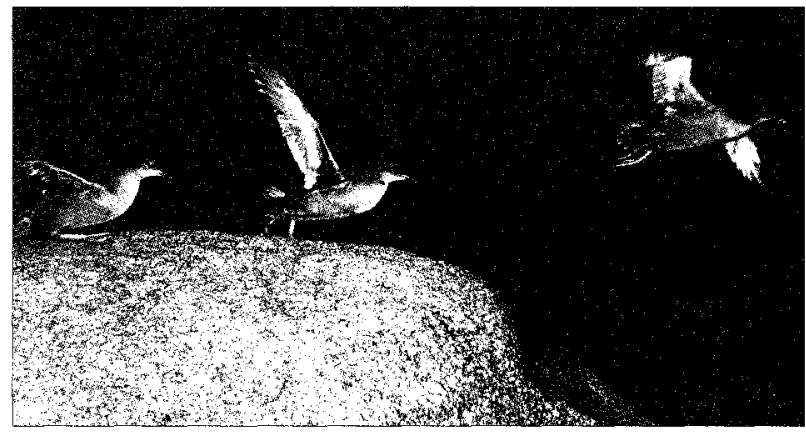

PLATE 15

Short-tailed Shearwaters, Puffinus tenuirostris, leaving their breedings grounds in Tasmania in April for their transequatorial migration.

of Dr Irynej Skira: a true field biologist. Paper presented to the Second International Manx Shearwater Workshop in Belfast, Northern Ireland.

Skira, S. 2005c: Irynej Skira 1950-2005. Emu 105: 343.

\section{PUBLICATIONS - IRYNEJ SKIRA}

Skira, I.J. 1977: The rabbit on Macquarie Island. Aurora. ANARE Club Journal (Midwinter 1977).

Skira, I.J. 1977: The Tasmanian muttonbird. Tasmanian Naturalist 49: 8 .

Skira, I.J. 1978: Reproduction of the rabbit, Oryctolagus cuniculus (L.) on Macquarie Island, subantarctic. Australian Wildlife Research 5: 317-326.

Jones, E. \& Skira, I.J. 1979: Breeding distribution of the Great Skua at Macquarie Island in relation to number of rabbits. Emи 79: 19-23.

Skira, I.J. 1979: Underwater feeding by Short-tailed Shearwaters. Emu 79: 43.

Skira, I.J. 1980: Some population parameters and seasonal changes in the weights of internal organs of rabbits, Oryctolagus cuniculus (L.) at Macquarie Island. Australian Wildlife Research 7: 235-245.

Skira, I.J. \& Wapstra, J.E. 1980: Occupation of burrows as a means of estimating harvest of Short-tailed Shearwaters in Tasmania. Еmu 80: 233-238.

Copson, G.R., Brothers, N.P. \& Skira, I.J. 1981: Distribution and abundance of the rabbit Oryctolagus cuniculus (L.) at subantarctic Macquarie Island. Australian Wildlife Research 8: 597-611.

Skira, I.J., Brothers, N.P. \& Copson, G.R. 1982: Coat colour and fitness of rabbits on Macquarie Island. Australian Wildlife Research 10: 121-123.

Brothers, N.P., Ebehard, I.E., Copson, G.R. \& Skira, I.J. 1982: Control of rabbits on Macquarie Island by Myxomatosis. Australian Wildlife Research 10: 477-485.

Skira, I.J., Brothers, N.P. \& Copson, G.R. 1983: Establishment of the European Rabbit flea on Macquarie Island. Australian Wildlife Research 10: 121-127.

Brothers, N.P \& Skira, I.J. 1983: Hippolyte Rocks, Tasmania. Seabird Islands No. 132. Corella 7: 80-82.

Fujimaki, Y. \& Skira, I.J. 1984: Notes on Latham's Snipe Gallinago hardwickii in Japan. Emu 84: 49-51.

Brothers, N.P. \& Skira, I.J. 1984: The Weka on Macquarie Island. Notornis 31: 145-154.

Skira, I.J. 1984: Breeding distribution of the Brown Skua on Macquarie Island. Emu 84: 248-249.

Skira, I.J. 1984: The rabbit on Macquarie Island. Tasmanian Naturalist 79: 14-15.

Towney, G. \& Skira, I.J. 1985: Seabird islands No. 139. Babel 
Island, Furneaux Group, Tasmania. Corella 8: 103-104.

Towney, G. \& Skira, I.J. 1985: Seabird islands No. 143,. Trefoil Island, Tasmania. Corella 8: 111-112.

Brothers, N.P., Skira, I.J. \& Copson, G.R. 1985: Biology of the feral cat, Felis catus L., on Macquarie Island. Australian Wildlife Research 12: 425-436.

Wooller, R.D., Skira, I.J. \& Serventy, D.L. 1985: Band wear on Short-tailed Shearwaters, Puffinus tenuirostris. Corella 9: $121-122$.

Skira, I.J. 1986: Food of the Short-tailed Shearwater, Puffinus tenuirostris, in Tasmania. Australian Wildlife Research 13: $481-488$

Skira, I.J., Wapstra, J.E., Towney, G.N. \& Naarding, J.I. 1986: Conservation of the Short-tailed Shearwater, Puffinus. tenuirostris, in Tasmania, Australia. Biological Conservation 37: $225-236$

Maruyama, N., Oka, N., Watabe, Y., Yuroda, N., Skira, I. \& Kohno, H. 1986: Reexamination of the migration route of Short-tailed Shearwaters, Puffinus tenuirostris. 36-42 (In Japanese).

Skira, I.J. \& Davis, G. 1987: The Short-tailed Shearwater colonies of King Island. Tasmanian Naturalist 90: 1-6

Skira, I.J. \& Brothers, N.P. 1987: Seabird Islands No. 172. Briggs Islat, Furneaux Group, Tasmania. Corella 11: 79-80.

Brothers, N.P. \& Skira, I.J. 1987: Seabird Islands No. 173. Chappel Island, Furneaux Group, Tasmania. Corella 11: 81-82.

Skira, I.J. \& Brothers, N.P. 1987: Seabird Islands No. 174. Battery Island, Furneaux Group, Tasmania. Corella 11: 83-84.

Oka, N., Maruyama, N. \& Skira, I.J. 1987: Chick growth and mortality of Short-tailed Shearwaters in comparison with Sooty Shearwaters, as a possible index of fluctuations of Australian Krill abundance. Proceedings of the National Polar Research symposium, Polar Biology 1: 166-174.

Skira, I.J. 1987: Socioeconomic aspects of muttonbirding in Tasmania, Australia. In Diamond, A.W. \& Filion, F.L. (eds): The Value of Birds. International Council for the Preservation of Birds Technical Publication 6: 63-75.

Wooller, R.D., Bradley, J.S., Serventy, D.L. \& Skira, I.J. 1.988: Factors contributing to reproductive success in Short-tailed Shearwaters Puffinus tenuirostris. Proceedings of the XIX International Ornithological Congress: 848-856.

Skira, I.J. \& Brothers, N.P. 1988: Seabird Islands No. 182. Billy Goat Reefs, Furneaux Group, Tasmania. Corella 12: $78-79$

Skira, I.J. \& Brothers, N.P. 1988: Seabird Islands No. 183. Little Green Island, Furneaux Group, Tasmania. Corella 12: $80-81$

Skira, I.J. \& Brothers, N.P. 1988: Seabird Islands No. 184 Great Dog Island, Furneaux Group, Tasmania. Corella 12: $82-84$.

Brothers, N.P \& Skira, I.J. 1988: Seabird Islands No. 185. Little Dog Island, Furneaux Group, Tasmania. Corella 12: 85-86.

Bradley,J.S., Wooller, R.D., Skira, I.J. \& Serventy, D.L. 1989: Age-dependent survival of breeding Short-tailed Shearwaters Puffinus tenuirostris. Journal of Animal Ecology 58: $175-188$

Pemberton, D. \& Skira, I.J. 1989: Elephant seals in Tasmania. Victorian Naturalist 106: 202-204.

Wooller, R.D., Bradley, J.S., Skira, I.J. \& Serventy, D.L 1989: Lifetime reproductive success in the Short-tailed Shearwater Puffinus tenuirostris. In Newton, I. (ed.) Lifetime Reproduction in Birds. Academic Press, London: 405-417.

Serventy, D.L., Gunn, B.M., Skira, I.J., Bradley, J.S. \& Wooller, R.D. 1989: Fledgling translocation and philopatry in a seabird. Oecologica 81: 428-429.

Skira, I.J. 1990: Human exploitation of the Short-tailed Shearwater (Puffinus tenuirostris). Papers and Proceedings of the Royal Society of Tasmania 124: 77-90.
Wooller, R.D., Bradley, J.S., Skira, I.J. \& Serventy, D.L. 1990: Reproductive success of Short-tailed Shearwaters Puffinus tenuirostris, in relation to their age and breeding experience. Journal of Animal Ecology 59: 161-170

Bradley, J.S., Wooller, R.D., Skira, I.J. \& Serventy, D.L 1990: The influence of mate retention and divorce upon reproductive success in Short-tailed Shearwaters, Puffinus tenuirostris. Joumal of Animal Ecology 59: 487-496.

Slater, J. \& Skira, I.J. 1990: The effect of the Exxon Valdez oil spill on Short-tailed Shearwaters. Tasmanian Naturalist 101: $1-4$.

Brothers, N.P \& Skira, I.J. 1990: Seabird Islands No. 202. Spences Reef, Furneaux Group, Tasmania. Corella 14: 67-68.

Skira, I.J. \& Wapstra, J.E. 1990: Control of Silver Gulls in Tasmania. Corella 14: 124-129.

Skira, I. 1991: Australian bird reviews No. 3. The Short-tailed Shearwater: a review of its biology. Corella 15: 45-52.

Bradley, J.S., Skira, I.J. \& Woolley, R.D. 1991: A long-term study of Short-tailed Shearwaters, Puffinus tenuirostris on Fisher Island, Tasmania. Ibis 133 Supplement 1: 55--61.

Skira, I. 1992: Commercial harvesting of Short-tailed Shearwaters (Tasmanian muttonbirds) In Meek, P. \& O'Brien, P. (eds): Wildlife Use and Management. Bureau of Rural Resources Report R/2/92: 7-18

Skira, I. 1993: Tasmanian Aborigines and Muttonbirding: a Historical Examination. Unpublished $\mathrm{PhD}$ thesis, University of Tasmania, Hobart.

Meathrel, C.M., Bradley, J.S., Wooller, R.D. \& Skira, I.J. 1993: The effect of parental condition on egg-size and reproductive success in Short-tailed Shearwaters, Puffinus tenuirostris. Oecologia 93: 162-164.

Meathrel, C.M., Skira, I.J., Bradley, J.S. \& Wooller, R.D. 1993 The influence of egg-size, mass and composition upon hatching success in the Short-tailed Shearwater, Puffinus tenuirostris (Aves: Procellariiformes). Journal of Zoology, London 230: 679-686.

Skira, I. 1994: C.H. Smith \& Co., of Launceston, a muttonbird buyer. Tasmanian Historical Research Association Papers and Proceedings 41: 163-176.

Bradley, J.S., Wooller, R.D. \& Skira, I.J. 1995: The relationship of pair-bond formation and duration to reproductive success in Short-tailed Shearwaters, Puffinus tenuirostris. Journal of Animal Ecology 64: 31-38.

Skira, I. 1995: A muttonbird in the hand. Natural History 104(8): August 24-35.

Pemberton, D., Gales, R. \& Skira, I. 1995: Interactions between seals and fisheries: a clash of vertebrate predators and pests. 10 $0^{\text {th }}$ Australian Vertebrate Pest Conference: 249-254

Skira, I. 1996: Aboriginal people and muttonbirding in Tasmania. In Bomford, M. \& Caughley, J. (eds): Sustainable Use of Wildlife by Aboriginal Peoples and Torres Strait Islanders. Australian Government Publishing Service, Canberra: $167-175$.

Oka, N., Maruyama, N., Kuroda, N. \& Skira, I. 1996: Colony site selection of Short-tailed Shearwaters in Tasmania. Journal of Yamashina Institute of Ornithology 28: 35-41.

Brothers, N., Pemberton, D., Gales, R. \& Skira, I. 1996: The status of seabirds in Tasmania. In Ross, G., Weaver, K. \& Greig, J. (eds): The Status of Australia's Seabirds: Proceedings of the National Seabird Workshop. Canberra 1-2 November, 1993. Biodiversity Group, Environment Australia, Canberra: 181-183.

Skira, I. 1997: Always afternoon: Aborigines on Cape Barron Island, in the nineteenth century. Tasmanian Historical Research Association Papers and Proceedings 44: 120-131.

Skira, I. 1997: Aboriginals in Tasmania: Living on Cape Barron Island in the twentieth century. Tasmanian Historical Research Association Papers and Proceedings 44: 187-201.

Skira, I. 1997: I hope you will be my "frend": Tasmanian Aborigines in the Furneaux Group in the ninereenth century - population and land tenure. Aboriginal History: 
21: $30-45$.

Walsh, D., Kirkpatrick, J.B. \& Skira, I.J. 1997: Vegetation patterns, environmental correlates and vegetation change in a Puffinus tenuirostris colony at Cape Queen Elizabeth, Tasmania. Australian Journal of Botany 45: 71-79.

Brothers, N.P., Pemberton, D. \& Skira, I. 1997: Seabird islands No. 234. Rum Island, Furneaux Group, Tasmania. Corella 21: 92-93.

Brothers, N.P., Pemberton, D. \& Skira, I. 1997: Seabird islands No. 235. Beagle Island, Furneaux Group, Tasmania. Corella 21: 94-96.

Bradley, J.S., Gunn, B.M., Skira, I.J., Meathrel, C.E. \& Wooller R.D. 1999: Age-dependent prospecting and recruirment to a breeding colony of Short-tailed Shearwaters, Puffinus tenuirostris. Ibis 141: 277-285.

Skira, I.J., Bothers, N.P. \& Pemberton, D. 1999: Distribution abundance and conservation status of Short-tailed Shearwaters, Puffinus tenuirostris in Tasmania. Marine Ornithology 24: 1-14.
Bradley, J.S., Wooller, R.D. \& Skira, I.J. 2000: Intermittent breeding in the Short-tailed Shearwater, Puffinus tenuirostris. Journal of Animal Ecology 69(4): 639-650.

Skira, I.J. \& Brothers, N.P. 2000: Seabird islands No. 246. Preservation Island, Furneaux Group, Tasmania. Corella 24: $45-46$.

Brothers, N.P. \& Skira, I.J. 2000: Seabird Islands No. 247. Little Chalky Island, Furneaux Group, Tasmania. Corella 24: 47-48.

Skira, I. 2003: Large mortality of Short-tailed Shearwaters Puffinus tenuirostris in Australia and New Zealand seas in October 2000. Corella 27(3): 81-84.

Skira, I. 2007: Shearwaters, Short-tailed and Sooty. In Riffenburgh, B. (ed.) Encyclopedia of the Antarctic volume $2 \mathrm{~L}-\mathrm{Z}$. Routledge, New York and London: 893-895.

(accepted 5 August 2008) 